\title{
PRODUKTIVITAS BUDIDAYA UDANG VANAME (Litopenaeus vannamei) TAMBAK SUPERINTENSIF DI PT. DEWI LAUT AQUACULTURE KABUPATEN GARUT PROVINSI JAWA BARAT
}

\section{PRODUCTIVITY OF VANAME SHRIMP CULTIVATION (Litopenaeus vannamei) SUPER INTENSIVE POND IN PT. DEWI LAUT AQUACULTURE GARUT DISTRICT, PROVINCE, JAWA BARAT}

\author{
Ulya Syofroul Lailiyah, Sinung Rahardjo, Maria G.E. Kristiany*, dan Mugi Mulyono \\ Teknologi Akuakultur, Sekolah Tinggi Perikanan Jakarta 12520, Indonesia \\ E-mail: maria.kritiany@kkp.go.id
}

Diterima: 22 Oktober 2018; diterima setelah perbaikan: 30 Oktober 2018; Disetujui: 5 November 2018

\begin{abstract}
ABSTRAK
Teknologi budidaya udang vaname superintensif menjadi orientasi sistem budidaya masa depan dengan konsep low volume high density. Budidaya yang terkontrol dengan manajemen limbah yang baik diharapkan menjadi satu sistem budidaya udang vaname yang produktif, menguntungkan dan berkelanjutan. Tujuan penelitian yaitu mengevaluasi performansi kinerja budidaya udang vaname, mengidentifikasi masalah dan merumuskan usulan intervensi serta menganalisis aspek ekonomi berkaitan dengan keuntungan yang diperoleh sesuai dengan usulan intervensi. Penelitian dilaksanakan bulan Februari - Mei 2018 di PT. DLA, Garut Jawa Barat. Penelitian menggunakan pendekatan deskriptif. Performansi kinerja budidaya yang diukur adalah produktivitas, SR, FCR, pertumbuhan dan kualitas air sebagai data pendukung, identifikasi masalah digunakan Root Cause Analysis dan Fishbone Analysis. Hasil menunjukkan produktivitas yang diperoleh sebesar 42 ton/ha dengan padat tebar 350 - 500 ekor/m², masa pemeliharaan 80 hari dengan ukuran size panen 78, serta persentase SR yang masih di bawah target yaitu $25 \%$ dengan nilai rata-rata SR 80\% dan FCR 20\% yang melebihi target, yaitu 1,7. Keuntungan sebesar Rp. 81.549.872 per tahun dengan nilai $\mathrm{B} / \mathrm{C}$ ratio 1,022 dengan tingkat persentase modal usaha PT. DLA adalah 10\%. Lost income dari performansi kinerja budidaya yang tidak sesuai dengan target produksi sebesar Rp. 593.535.999 per tahun.
\end{abstract}

Kata Kunci: Udang vanname, Fishbone, produktivitas, superintensif, IMNV

\section{ABSTRACT}

The technology of super-intensive vaname shrimp cultivation is the orientation of the future cultivation system with the concept of low volume high density. Controlled cultivation with good waste management is expected to be a productive, profitable and sustainable vaname shrimp farming system. The purpose of the study was to evaluate the performance of vaname shrimp farming performance, identify problems and formulate proposed interventions and analyze economic aspects related to the benefits obtained in accordance with the proposed intervention. The study was conducted in February - May 2018 at PT. DLA, Garut, West Java. The study used a descriptive approach. The results showed that the productivity obtained was 42 tons / ha with stocking density of 350-500 individuals / m2, maintenance period of 80 days with size of harvest size 78, and the percentage of SR which was still below the target of $25 \%$ with an average value of SR $80 \%$ and $20 \%$ FCR that exceeds the target, which is 1.7. Profit of Rp. 81,549,872 per year with a B/C ratio of 1.022 with a percentage level of business capital of PT. DLA is $10 \%$. Lost income from the performance of cultivation performance that is not in accordance with the production target of Rp. 593,535,999 per year.

Keywords: Vanname Shrimp, Fishbone, productivity, superintensive, IMNV

Copyright @ JKPT Juni 2018

Produktivitas Budidaya Udang Vanname.........Lailiyah, et.al 


\section{PENDAHULUAN}

Udang memiliki kontribusi cukup besar bagi ekonomi perikanan nasional. Berdasarkan data International Trade Center (2017), permintaan udang dunia dalam periode 2012 - 2016 mengalami pertumbuhan sebesar 7,45 persen per tahun. Udang vaname masih menjadi tumpuan yang strategis untuk upaya pencapaian target produksi udang nasional. Teknologi budidaya udang vaname superintensif menjadi orientasi sistem budidaya masa depan dengan konsep Low volume high density, yaitu dikembangkan dengan tidak memerlukan lahan yang luas sehingga mudah dikontrol, namun memiliki produktivitas yang tinggi.

Lingkungan dan hamparan budidaya yang terkontrol dengan manajemen limbah yang baik diharapkan menjadi satu sistem budidaya udang vaname yang produktif, menguntungkan dan berkelanjutan. Upaya yang dapat ditempuh adalah dengan mengembangkan sistem produksi udang yang memiliki tingkat produktivitas tinggi melalui pemanfaatan lahan tambak yang minimal. Target produksi udang masih dihadapkan pada berbagai tantangan, satu diantaranya adalah manajemen budidaya yang mampu menghasilkan tingkat produktivitas yang tinggi.

Saat ini PT. DLA menerapkan inovasi teknologi terbaru yaitu tambak supraintensif. Penerapan teknologi ini diharapkan mampu meningkatkan produktivitas lahan dan meningkatkan pendapatan perusahaan. Untuk itu penelitian tentang performansi kinerja budidaya tambak supraintensif di PT. DLA perlu dilakukan.

Tujuan penelitian ini adalah mengevaluasi performansi kinerja budidaya udang vaname, mengidentifikasi masalah dan merumuskan usulan intervensi pada budidaya udang vaname serta menganalisis aspek ekonomi berkaitan dengan keuntungan yang diperoleh sesuai dengan usulan intervensi.

\section{BAHAN DAN METODE}

Penelitian ini dilaksanakan pada bulan Februari hingga Mei 2018 di PT. Dewi Laut Aquaculture, Desa Cigadog, Kecamatan Cikelet, Kabupaten Garut, Provinsi Jawa Barat. Penelitian ini menggunakan pendekatan deskriptif dengan mengamati dan mengikuti seluruh rangkaian proses produksi di perusahaan. Data yang dikumpulkan meliputi seluruh komponen sumberdaya yang digunakan dalam proses produksi yaituu: bahan atau material yang digunakan, metode atau SOP yang dijalankan, sarana prasarana yang dimiliki dan sumberdaya manusia yang bekerja di perusahaan tersebut termasuk data siklus sebelumnya dan biaya produksi yang dikeluarkan.

Performansi kinerja budidaya yang diukur adalah produktivitas, SR, FCR serta pertumbuhan dan kualitas air sebagai data pendukung. Analisis performansi kinerja budidaya menggunakan SOP yang berlaku di perusahaan dan beberapa literatur yang mendukung, seperti SNI 01.7246-2006, Kepmen KP no.28/permen-kp/2004, Kepmen KP no.75/permen-kp/2016 dan Tahe dkk., (2014). 
Tabel 1. Indikator Performansi Budidaya dan Standar yang digunakan Table 1. Aquaculture Performance Indicators and Standards

\begin{tabular}{|c|c|c|c|c|}
\hline No & Indikator & Kriteria & Kisaran & Referensi \\
\hline \multirow{3}{*}{1} & \multirow{3}{*}{ Produktivitas } & Umur pemeliharaan & $\begin{array}{l}100 \text { hari } \\
120 \text { hari }\end{array}$ & $\begin{array}{c}\text { SOP } \\
\text { Kep.75/Men/2016 } \\
\end{array}$ \\
\hline & & Tonase panen & $\begin{array}{l}49 \text { ton } / \text { ha } \\
63 \text { ton/ha }\end{array}$ & $\begin{array}{c}\text { SOP } \\
\text { Tahe dkk. (2014) }\end{array}$ \\
\hline & & Luas petakan & $\begin{array}{l}400 \mathrm{~m}^{2} \\
1000 \mathrm{~m}^{2}\end{array}$ & $\begin{array}{c}\text { SOP } \\
\text { Tahe dkk. (2014) }\end{array}$ \\
\hline \multirow{3}{*}{2} & \multirow{3}{*}{ SR } & Jumlah tebar & 200.000 ekor & SOP \\
\hline & & Populasi panen & $\begin{array}{l}>75 \% \\
80 \% \\
85 \% \\
\end{array}$ & $\begin{array}{c}\text { SNI 01.7246-2006 } \\
\text { SOP } \\
\text { Tahe dk(2014) }\end{array}$ \\
\hline & & Padat tebar & $500-1000$ ekor $/ \mathrm{m}^{2}$ & $\begin{array}{c}\text { SOP } \\
\text { Tahe dkk. (2014) }\end{array}$ \\
\hline 3 & FCR & Nilai FCR & 1,5 & $\begin{array}{c}\text { SOP } \\
\text { Tahe dkk. (2014) }\end{array}$ \\
\hline 4 & $\mathrm{ADG}$ & $\begin{array}{l}\text { Penambahan berat rata- } \\
\text { rata }\end{array}$ & $\begin{array}{l}0,2 \mathrm{~g} / \text { hari } \\
0,23 \mathrm{~g} / \text { hari }\end{array}$ & $\begin{array}{l}\text { SOP DLA } \\
\text { SOP CPP }\end{array}$ \\
\hline \multirow{6}{*}{5} & \multirow{6}{*}{ Kualitas air } & Suhu & $25-31,5^{\circ} \mathrm{C}$ & SNI 01.7246-2006 \\
\hline & & $\mathrm{DO}$ & $3,0-7,5 \mathrm{mg} / \mathrm{l}$ & Kep.28/Men/2004 \\
\hline & & Salinitas & $15-34 \mathrm{~g} / \mathrm{l}$ & Edhy dkk. (2010) \\
\hline & & $\mathrm{pH}$ & $7,5-8,5$ & SNI 01.7246-2006 \\
\hline & & Amonia & $<0,05 \mathrm{mg} / 1$ & Kep.75/Men/2016 \\
\hline & & Nitrit & $0,05-0,10 \mathrm{mg} / \mathrm{l}$ & SNI 01.7246-2006 \\
\hline
\end{tabular}

Identifikasi masalah pada performansi kinerja budidaya dianalisis menggunakan Root Cost Analysis terkait dalam pegelolaan sumberdaya manusia, metode pelaksanaan produksi, material yang digunakan serta saraa dan prasarana berupa mesin yang digunakan. Kemudian data dianalisis menggunakan Fish Bone Diagram.

Aspek ekonomi dianalisis kelayakan finansial menggunakan Laba/Rugi, Benefit Cost Ratio (B/C ratio), Break Even Point (BEP), Paback Periode (PP) dan Return on Investment (ROI). Analisis aspek ekonomi menggunakan laba/rugi penjualan yang diperoleh sesuai dengan prioritas

Copyright @ JKPT Juni 2018

Produktivitas Budidaya Udang Vanname.........Lailiyah, et.al usulan pemecahan masalah yang dianalisis menggunakan skoring.

\section{HASIL DAN PEMBAHASAN}

Produktivitas pada modul A superintensif, sejumlah 5 kolam yang diamati selama penelitian, rata-rata produktivitas yang dihasilkan pada siklus 6 masih di bawah target perusahaan. Produktivitas yang ditargetkan per petak yaitu sebanyak 49 ton/ha, sedangkan rata-rata produktivitas yang dihasilkan yaitu 42 ton/ha. Nilai tersebut tergolong masih rendah untuk budidaya udang superintensif. Produktivitas yang telah 
dicapai oleh Tahe $d k k$. (2014), berdasarkan ekor $/ \mathrm{m}^{2}$, diperoleh produktivitas sebesar 63 penelitiannya pada padat tebar udang 500 ton/ha pada masa pemeliharaan 110 hari

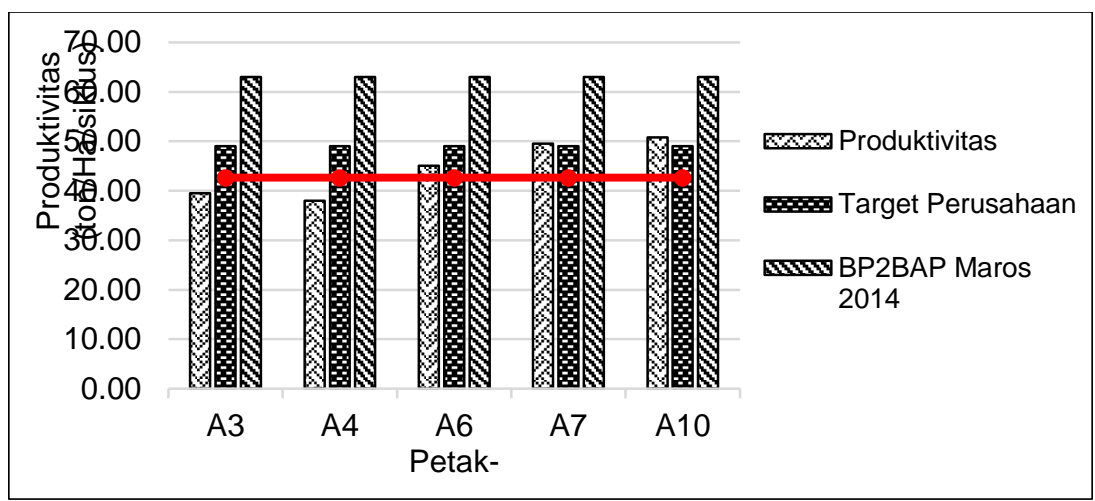

Gambar 1. Produktivitas budidaya udang vaname PT. Dewi Laut Aquaculture Figure 1. Productivity of Vanname shrimp farming PT. Dewi Laut Aquaculture

Nilai produktivitas tertinggi yaitu pada petak A10 dan terendah pada petak A4. Persentase produktivitas lahan budidaya superintensif, sebesar $40 \%$ yang belum mencapai target produksi. Adanya perbedaan yang dihasilkan, diduga dipengaruhi oleh beberapa faktor seperti jumlah tebar, umur pemeliharaan, tonase panen dan berat rata-rata akhir udang.

Produktivitas pada petak A4 sebesar 38 ton/ha, sedangkan pada petak A10, produktivitas melebihi target yaitu 50,75 ton/ha. Hal ini pengaruhi oleh perbedaan jumlah tebaran benur dari kolam pendederan (Nursery Pond) di petak A4 lebih rendah, dibandingkan dengan kolam A10 yang jumlah tebaran lebih tinggi. Pernyataan tersebut sesuai dengan pendapat Rachmansyah $d k k$. (2017), bahwa penebaran yang optimal akan berdampak pada produktivitas dan keuntungan yang maksimal dengan sistem produksi yang berkelanjutan.

Selain itu, umur pemeliharaan mempengaruhi nilai produktivitas. Umur pemeliharaan udang yang perusahaan targetkan yaitu 100 hari, namun di umur pemeliharaan ke 70 hari, udang mengalami mortalitas setelah dilakukannya panen parsial. Adanya mortalitas disebabkan udang stress pasca panen parsial, sehingga memicu munculnya penyakit IMNV. Kemudian penyakit menyebar ke petakan lainnya, permasalahan tersebut mengakibatkan udang dipanen pada umur pemeliharaan 72 - 88 hari. Masa pemeliharaan yang belum mencapai 100 hari, menjadikan berat rata-rata udang masih di bawah target, sehingga mempengaruhi produktivitas yang belum sesuai target produksi.

\section{SR (Survival Rate)}

SR panen pada kolam pembesaran, sesuai dengan SOP yang ditetapkan oleh perusahaan disajikan pada Gambar 16. SR udang yang diperoleh selama 60 hari pada kolam pembesaran sebesar $40 \%$ yang belum mencapai target. Petak A3 nilai SR masih di bawah target, yaitu sebesar $60 \%$. 


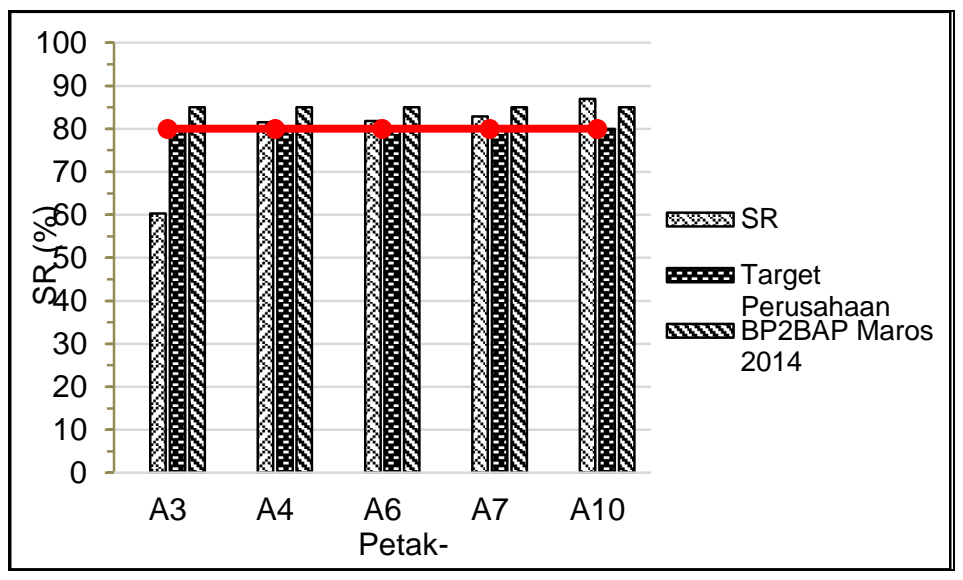

Gambar 2. Survival Rate pada kolam pembesaran modul A

Figure 2. Survival Rate at module A enlargement pond

Rendahnya SR pada petak A3, disebabkan adanya mortalitas yang tinggi akibat terserangnya penyakit IMNV. Hal ini sejalan dengan pendapat Sukenda $d k k$. (2011) yang menyatakan bahwa, penyakit IMNV dapat mengakibatkan mortalitas pada udang vaname.

\section{FCR (Food Convertion Ratio)}

Nilai FCR tertinggi yaitu pada petak A3 sebanyak 1,7 melebihi FCR maksimal target dan FCR menurut Tahe $d k k$. (2014), sedangkan FCR terendah didapat 1,3 pada petak A4. Adanya perbedaan nilai FCR tersebut dipengaruhi oleh menurunnya tingkat nafsu makan udang akibat penyakit IMNV dan kurang tepatnya perhitungan dalam pendugaan populasi udang, sehingga menyebabkan jumlah pemberian pakan tidak sesuai. Hal ini sesuai dengan pendapat Andrade et al. (2008) dalam Sukenda dkk. (2011), bahwa udang yang terjangkit penyakit IMNV selain terjadi mortalitas, tingkat nafsu makan udang menurun dan mengakibatkan meningkatnya FCR. Nilai FCR pada masing-masing petak disajikan pada Gambar 3.

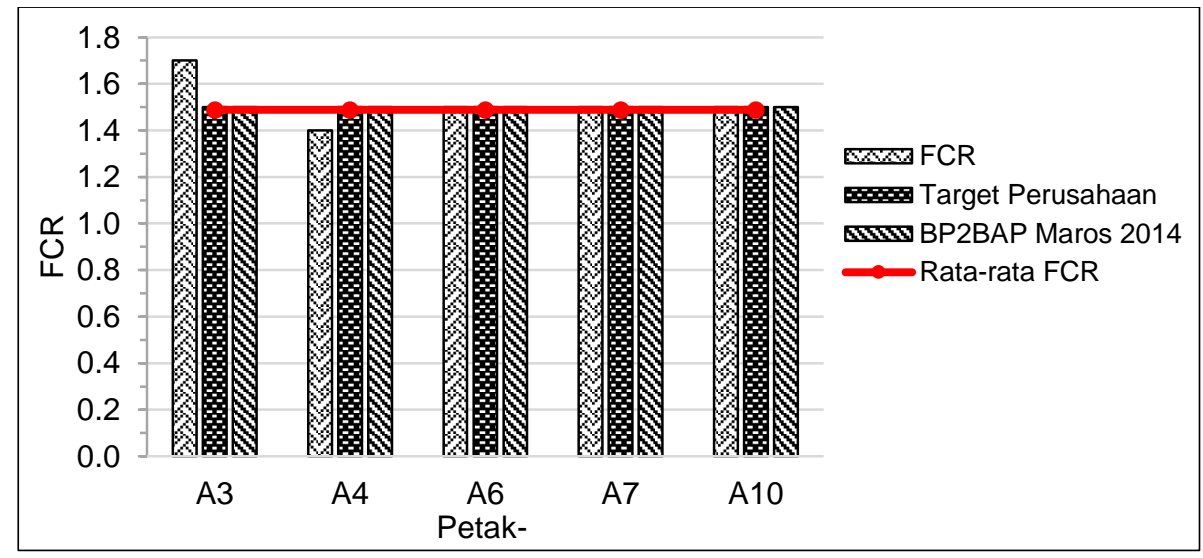

Gambar 3. Food Convertion Ratio di modul A

Figure 3. Food Convertion Ratio in module A 


\section{Pertumbuhan}

Pertumbuhan rata-rata berat akhir udang yang dipelihara selama 82 hari menunjukkan hasil yang bervariasi dari waktu ke waktu seiring dengan meningkatnya waktu pemeliharaan. Pertumbuhan udang vaname pada padat penebaran 350-500 ekor $/ \mathrm{m}^{2}$, dibandingkan dengan standar program pakan dari perusahaan pakan yang digunakan perusahaan sebagian acuan pertumbuhan dan hasil yang diperoleh yaitu masih di bawah target. Berat rata-rata akhir udang tertinggi, terdapat pada petak A3 sebesar 14,21 g/ekor dan terendah pada petak A10 yaitu 10,91 g/ekor. Sedangkan pada petak A6 dipanen di umur pemeliharaan ke 72, disebabkan adanya mortalitas yang tinggi akibat terserang penyakit IMNV dengan berat rata-rata akhir sebesar 10,83 g/ekor.
Berat rata-rata udang yang diperoleh dari kelima petak tersebut, tidak jauh berbeda dengan Tahe dan Makmur (2016), pada penelitiannya pengaruh padat penebaran terhadap produksi udang vaname superintensif skala kecil, yaitu pada padat tebar $600 \mathrm{ekor} / \mathrm{m}^{2}$ diperoleh berat ratarata akhir $10 \mathrm{~g} /$ ekor, selama umur pemeliharaan 80 hari. Suwardi $d k k$. (2014) dalam Tahe dan Makmur (2016), padat tebar 500 ekor $/ \mathrm{m}^{2}$ diperoleh berat rata-rata akhir 14,89 g/ekor. Sehingga pertumbuhan udang vaname dipengaruhi oleh padat penebaran, semakin tinggi padat tebar maka berat rata-rata udang semakin menurun. Pertumbuhan udang yang diperoleh disebabkan adanya persaingan ruang gerak dalam media budidaya.

Lebih jelasnya Grafik pertumbuhan dapat dilihat pada Gambar 4 dan 5.

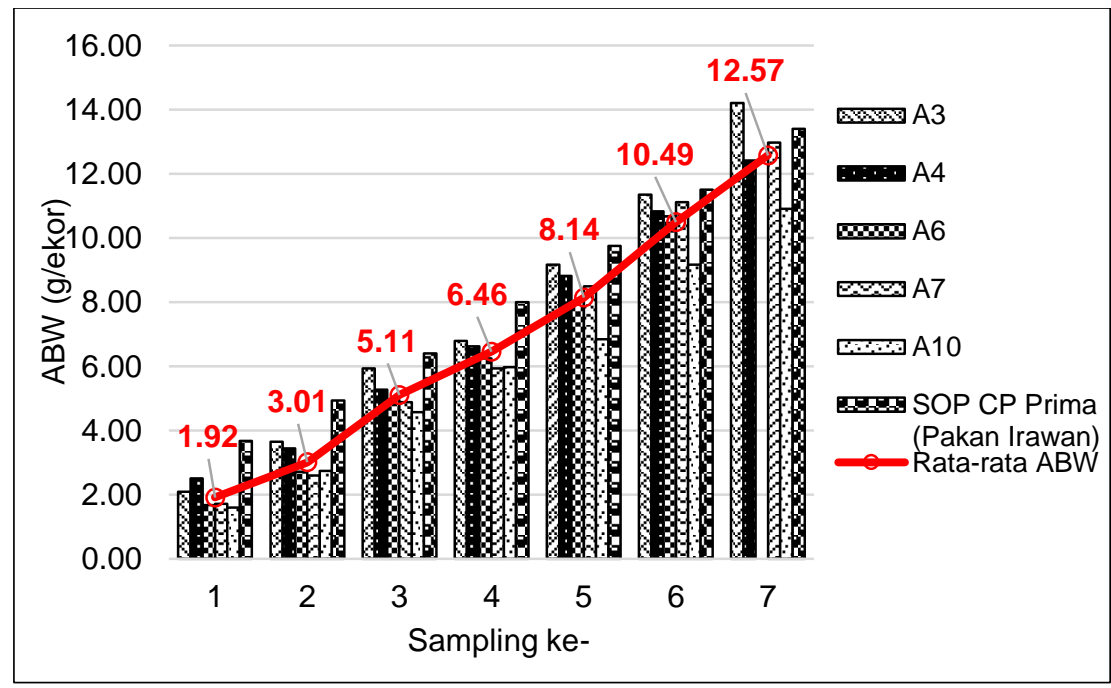

Gambar 4. Average Body Weight (ABW)

Figure 4. Average Body Weight (ABW) 


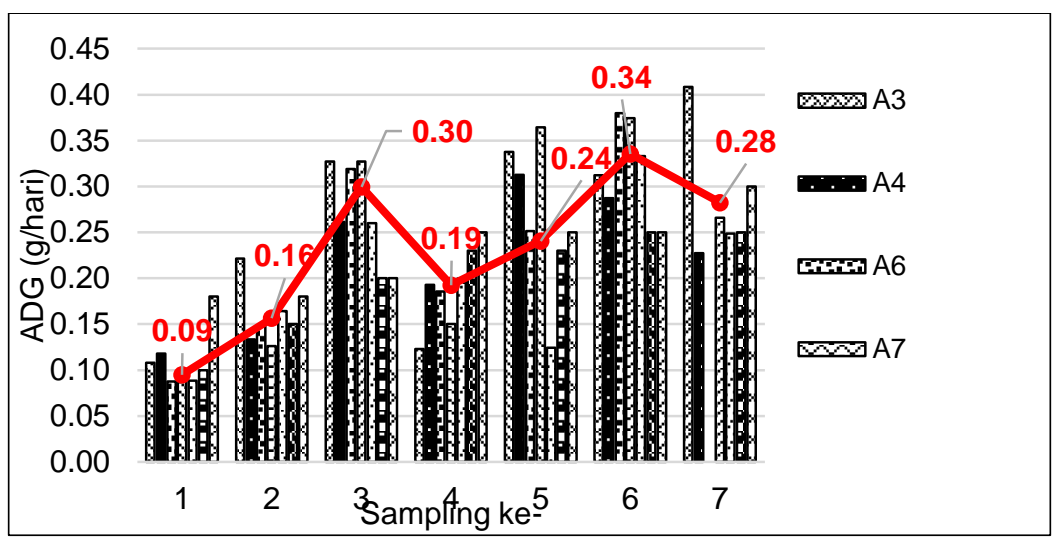

Gambar 5. Average Daily Growth (ADG)

Figure 5. Average Daily Growth (ADG)

Berdasarkan Gambar 5, laju pertumbuhan berat harian mengalami fluktuasi. Pada umur pemeliharaan ke 35 - 60 hari, di sampling pertama hingga sampling ke tiga pertumbuhan normal, tetapi di sampling ke empat, pertumbuhan mengalami penurunan, hal ini diikuti dengan menurunnya kondisi kualitas air di pertengahan budidaya. Selanjutnya pada sampling ke 5, pertumbuhan kembali naik, setelah dilakukannya panen parsial dengan mengurangi $20-30 \%$ biomassa udang yang bertujuan meningkatkan carring capacity, sehingga laju pertumbuhan udang kembali naik, tetapi risiko dari dilakukannya panen parsial, yaitu mengakibatkan udang stress dan memicu munculnya penyakit. Oleh sebab itu, pada petak A6 dipanen total, 3 hari usai dilakukan panen parsial, akibat adanya mortalitas yang semakin tinggi. Rata-rata laju pertumbuhan per hari di kelima petak pada akhir budidaya cenderung normal yaitu $0,22 \mathrm{~g} /$ hari. Hasil tersebut sesuai dengan pertumbuhan yang perusahaan targetkan.

\section{Pembahasan}

\section{Performansi Kinerja Budidaya}

Hasil performansi kinerja budidaya di PT. Dewi Laut Aquaculture di siklus 6, ditemukan adanya permasalahan sehingga target perusahaan belum tercapai. Berikut target produksi dari hasil produksi di siklus 6 yang belum mencapai target disajikan pada Tabel 2.

Tabel 2. Target dan hasil produksi PT. Dewi Laut Aquaculture

Table 2. Target and production results of PT. Dewi Laut Aquaculture

\begin{tabular}{|c|c|c|c|}
\hline No & Uraian & Target Produksi & Hasil Produksi \\
\hline 1 & Produktivitas ton/Ha & 49 & $38,00-50,75$ \\
\hline 2 & Survival Rate (SR) $\%$ & 80 & $58,76-86,58$ \\
\hline 3 & Food Convertion Ratio (FCR) & Maks 1,5 & $1,4-1,7$ \\
\hline
\end{tabular}


Berdasarkan permasalahan tersebut, Selanjutnya identifikasi masalah disajikan pada masalah diidentifikasi menggunakan Fishbone Gambar 6. Analysis. Untuk mendapatkan akar masalahnya.

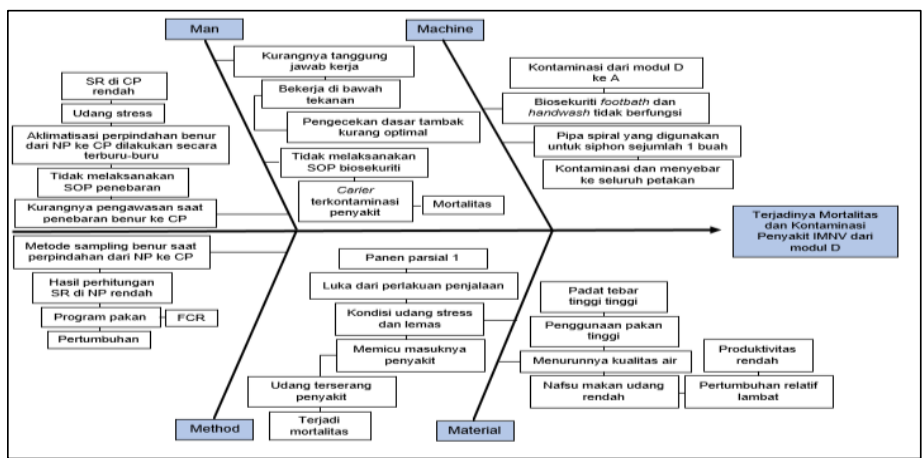

Gambar 6. Identifikasi masalah menggunakan Fishbone Analysis

Figure 6. Identification of problems using Fishbone Analysis

Belum tercapainya target produksi dipengaruhi oleh faktor lain yang saling berkaitan, antara SR, FCR, pertumbuhan dan kualitas air. Jika dilihat dari target produksi, rata-rata tonase panen di masing-masing petak adalah 2 ton dengan jumlah tebar benur rata-rata 200.000 ekor dan mempertimbangkan target Survival Rate (SR) serta Average Body Weight (ABW) udang mencapai $80 \%$ dengan berat rata-rata udang per ekor sekitar 15 gram.

Rendahnya hasil produksi di modul A disebabkan adanya mortalitas yang tinggi akibat terserangnya penyakit IMNV. Munculnya penyakit IMNV sendiri disebabkan kontaminasi dari modul D yang telebih dahulu terjangkit penyakit IMNV yang terbawa oleh manusia sebagai carrier, akibat tidak berfungsinya footbath sebagai biosekuriti, serta dipicu dari kondisi kualitas air yang menurun dan kondisi udang yang lemah, pasca dilakukannya panen parsial di umur pemeliharaan 70 hari, mengakibatkan penyakit cepat menyebar. Penyebaran penyakit diperparah dari kontaminasi pipa spiral yang digunakan secara bergantian saat penyiponan dasar tambak, sehingga penyakit menyebar ke seluruh petakan di modul A. Oleh sebab itu terjadi mortalitas yang tinggi akibat penyakit IMNV.

Kurangnya rasa tanggungjawab yang oleh feeder, dikarenakan penghargaan bonus penjualan yang minim pada siklus sebelumnya, sehingga pekerjaan dilaksanakan di bawah tekanan, pengecekan dasar tambak kurang optimal, akibatnya pengelolaan kualitas air kurang maksimal. Manusia menjadi carrier penyakit, kontaminan dari modul D ke modul A, akibat dari tidak menerapkan fungsi footbath sebagai biosekuriti.

Petak A4 produktivitas paling rendah, dikarenakan estimasi populasi dari perhitungan perpindahan benur dari kolam pendederan hanya 136.543 ekor dari jumlah tebar benur di awal pemeliharaan sebanyak 200.000 ekor. Penurunan 
SR sebanyak $60 \%$ pada saat perpindahan benur dari kolam pendederan ke kolam pembesaran, disebabkan adanya permasalahan di awal pemeliharan di kolam pendederan.

Permasalahannya lainnya yaitu adanya manajemen kualitas air yang kurang optimal yang menyebabkan udang stress, sehingga memicu terserangnya penyakit IMNV dan dilakukan tindakan panen total sebelum masa pemeliharaan 100 hari. Panen total yang dilakukan pada umur pemeliharaan 77 hari dengan ABW udang 11,25 g/ekor dan masih di bawah target, sehingga produktivitas yang ditargetkan pada keseluruhan kolam belum sesuai target disebabkan oleh penyakit IMNV.

Penyebab dari belum tercapainya SR dipengaruhi beberapa faktor meliputi, pengelolaan sumberdaya manusia dalam pelaksanakan SOP kurang dijalankan secara optimal, penerapan biosekuriti masih belum dijalankan yang mengakibatkan kontaminasi penyebaran penyakit. Selain itu, metode dalam sampling yang dilakukan di kolam pendederan saat akan dipindahkan ke kolam pembesaran tidak akurat, yakni hanya mengambil sampel benur dari satu titik di pinggiran kolam dengan tidak dibatasai jumlah minimal atau maksimal untuk menyamakan perhitungan untuk kolam lainnya, akibatnya SR yang didapat pada kolam pendederan rendah.

Faktor lainnya yang menjadi penyebab SR belum sesuai dengan target, yaitu padat tebar benur yang tinggi $350-500$ ekor $/ \mathrm{m}^{2}$, mengakibatkan penurunan kualitas air dari pemberian pakan yang

Copyright (C) JKPT Juni 2018

Produktivitas Budidaya Udang Vanname.........Lailiyah, et.al berlebih sehingga memicu munculnya penyakit IMNV dan terjadi mortalitas. Menyebarnya penyakit IMNV hingga ke seluruh petak dikarenakan adanya kontaminasi alat sipon yang digunakan saat penyiponan. Pipa spiral yang digunakan untuk sipon hanya berjumlah satu dan digunakan secara bergantian untuk 10 petak. Prosedur yang ada tidak dikerjakan dengan baik dan kurang adanya kesigapan tindak lanjut untuk melapor pengadaan pipa spiral baru di masingmasing sejumlah kolam.

\section{Usulan Pemecahan Masalah}

Identifikasi masalah dari performansi kinerja budidaya yang telah dilakukan, terdapat beberapa usulan pemecahan dari permasalahan tersebut. Melaksanakan SOP dalam pengecekan dasar tambak 2 kali seminggu, mengisi footbath secara berkala untuk meminimalisir terjadinya kontaminasi kembali dari footbath yang ada di masing-masing modul belum dilaksanakan dan menerapkan fungsi footbath sebagai biosekuriti sehingga manusia sebagai carrier penyakit dapat dicegah masuk ke tambak

Metode sampling saat pindah benur dari NP ke CP dilakukan di beberapa titik sampel, pengupayakan seakurat mungkin dalam penentuan berat individu udang untuk menghindari kesalahan dalam estimasi populasi dan penentuan jumlah pakan harian.

Melakukan training atau pelatihan kepada karyawan untuk menambah wawasan mdan pengetahuan, sehingga SOP perusahaan dijalankan sebagai suatu keharusan dan muncul dari kesadaran diri sendiri, menambah jumlah 
pipa spiral untuk masing-masing petakan terdapat 1 buah pipa spiral, untuk meminimalisir penyebaran penyakit ke petak budidaya lainnya, jika udang terjangkit penyakit virus dan memberikan penghargaan kepada karyawan yang melaksanakan SOP, bertujuan agar karyawan lebih bersemangat menjalankan pekerjaannya dengan merasakan hasil dari SOP yang dijalankannya.

\section{Aspek Ekonomi}

Analisis aspek ekonomi digunakan untuk menjelaskan mengenai hasil finansial dari usaha budidaya udang vaname superintensif di PT. Dewi Laut Aquaculture. Berikut hasil perhitungan analisis finansial disajikan pada Tabel 3.

Pendapatan yang diterima perusahaan yaitu mengalami keuntungan per tahun yakni sebesar Rp. 82.469.872 dengan nilai $\mathrm{B} / \mathrm{C}$ ratio 1,022 .
Maka usaha tersebut dikatakan layak dan mendekati nilai impas. BEP atau titik impas akan diperoleh, pada produksi udang sebanyak 48.222 kg dengan BEP harga Rp. 3.419.016.096 dan waktu yang diperlukan untuk mengembalikan biaya investasi yaitu 4 tahun 7 bulan 9 hari dengan tingkat persentase modal usaha PT. Dewi Laut Aquaculture adalah 10\%.

Berdasarkan performansi kinerja budidaya, terdapat beberapa petak yang belum sesuai dengan target perusahaan. Adapun indikator permasalahan tersebut memiliki pengaruh terhadap pendapatan perusahaan, yakni SR dan FCR. Rata-rata dari nilai SR dan FCR yang dihasilkan memberikan lost income yang seharusnya dicapai oleh perusahaan. Lost income dari performansi kinerja budidaya yang tidak sesuai dengan target produksi sebesar Rp. 593.535.999 per tahun.

Tabel 3. Hasil Perhitungan Analisis Finansial

Table 3. Results of Financial Analysis Calculation

\begin{tabular}{|c|c|c|}
\hline No. & Indikator & Jumlah (Rp.) \\
\hline 1 & Biaya investasi & 831.283 .930 \\
\hline 2 & Biaya penyusutan/tahun & 97.997 .686 \\
\hline 3 & Biaya variabel/tahun & 2.861 .512 .384 \\
\hline 4 & Biaya tetap & 819.221 .405 \\
\hline 5 & Biaya operasional & 3.680 .737 .790 \\
\hline \multirow{4}{*}{6} & Penjualan & \\
\hline & Siklus 4 & 1.510 .852 .606 \\
\hline & Siklus 5 & 1.385 .115 .300 \\
\hline & Siklus 6 & 866.235 .757 \\
\hline 7 & Total penjualan & 3.763 .203 .663 \\
\hline 8 & Analisis R/L & 82.469 .872 \\
\hline 9 & Analisis B/C ratio & 1,022 \\
\hline 10 & $\begin{array}{l}\text { BEP } \\
\text { Unit (kg) } \\
\text { Harga }\end{array}$ & $\begin{array}{r}48.222 \\
3.419 .016 .096\end{array}$ \\
\hline 11 & PP (tahun) & 4,61 \\
\hline 12 & ROI & $10 \%$ \\
\hline
\end{tabular}




\section{KESIMPULAN}

Performansi kinerja budidaya meliputi produktivitas $60 \%$, SR 40\%, dan FCR $20 \%$ belum mencapai target produksi. Akar permasalahan yang ditimbulkan yaitu penyakit IMNV yang menyebakan perfomansi kinerja budidaya belum mencapai target produksi

Perusahaan memperoleh keuntungan sebesar Rp. 82.469.872 per tahun dengan nilai $\mathrm{B} / \mathrm{C}$ ratio 1,022. BEP unit $48 \mathrm{~kg}$ atau BEP harga $\mathrm{Rp}$. 3.419.016.096, PP 4 tahun 7 bulan 9 hari dengan tingkat persentase modal usaha PT. Dewi Laut Aquaculture adalah 10\%. Lost income dari performansi kinerja budidaya yang tidak sesuai dengan target produksi sebesar Rp. 593.535.999 per tahun.

\section{DAFTAR PUSTAKA}

Direktorat Jendral Perikanan Budidaya Kementerian Perikanan dan Kelautan. 2017. Target Perikanan Budidaya. Jakarta.

Keputusan Menteri Kelautan dan Perikanan Nomor : KEP. 28/MEN/2004 Tentang Pedoman Umum Budidaya Udang di Tambak.

Keputusan Menteri Kelautan dan Perikanan Nomor : KEP. 75/MEN/2016 Tentang
Pedoman Umum Pembesaan Udang Winduu (Penaeus monodon) dan Udag Vaname (Litopenaes vannamei).

Rahmansyah, M \& Fahrur, M. 2017. Budidaya Udang Vaname dengan adat Penebaran Tinggi. Media Akuakultur, 12 (1), 2017, 19-26.

SNI 01.7246-2006. Produksi Udang Vaname di Tambak Dengan Teknologi Intensif.

Sukenda, Nuryati, S. \& Sari, I. R. 2011. Pemberian meniran Phyllanthus niruri untuk pencegahan infeksi IMNV (infectious myonecrosis virus) pada udang vaname Litopenaeus vannamei. Jurnal Akuakultur Indonesia 10 (2), 192-202 (2011).

Tahe, S \& Suwoyo. 2011. Pertumbuhan dan Sintasan Udang Vaname (Litopenaeus vannamei) dengan Kombinasi Pakan Berbeda dalam Wadah Terkontrol. Marros. J. Ris. Akuakultur Vol.6 No.1 Tahun 2011: 31-40.

Tahe, S \& Makmur. 2016. Pengaruh Padat Penebaran terhadap Produksi Udang Vaname (Litopenaeus vannamei) Superintensif Skala Kecil. Prosiding Forum Inovasi Teknologi Akuakultur 2016.

Tahe, S., Mangampa, M \& Makmur. (2014). Kinerja budidaya udang vaname (Litopenaeus vannamei) pola super intensif dan analsis biaya. Prosiding Forum Inovasi Teknologi Akuakultur 2014, p. 23-30. 